\title{
Assessing inter-organizational performance through customer value: a literature review
}

\author{
Lucrezia Coletta and Milena Vainieri \\ Institute of Management and Department EMbeDS, Sant'Anna School of Advanced Studies, Pisa, Italy \\ Guido Noto \\ Department of Economics, University of Messina, Messina, Italy, and \\ Anna Maria Murante \\ Institute of Management and Department EMbeDS, Sant'Anna School of Advanced Studies, Pisa, Italy
}

\begin{abstract}
Purpose - This study aims to systematically review the literature on the use of customer value for the evaluation of inter-organizational performance, with a wide perspective embracing different contexts and settings.

Design/methodology/approach - Searching within the Scopus and ISI Web of Science databases, a systematic literature review has been conducted analyzing 41 papers published between 1991 and 2020.

Findings - Categorization of customer value and inter-organizational performance measures were developed and the main differences among different settings were discussed.

Practical implications - The results presented in this study may be helpful for practitioners and managers who, in the completion of their activities, have to maintain strong and frequent relationships with other organizations. In fact, practitioners and managers interested in enhancing customer value and measuring inter-organizational performance may find an innovative perspective linking the two dimensions. They could find the categorizations presented in this study as a starting point for developing a performance evaluation framework suitable for evaluating their present business relationships. In fact, the categorizations provide a panorama of how scholars have measured until now inter-organizational performance through customer value, and therefore, they could choose the measures more appropriate for their situation.

Originality/value - No systematic literature review of the use of customer value for assessing inter-organizational performance has previously been undertaken, especially considering different settings.
\end{abstract}

Keywords Customer value, Performance evaluation, Inter-organizational performance, Dyadic, Service network

Paper type Research Article

\section{Introduction}

The evaluation of inter-organizational performance is a widely investigated and debated area of research, but it still poses several open questions due to its complexity.

The importance of measuring inter-organizational performance must be found in the need to have a more objective as a possible tool able to inform managers on the convenience of maintaining the relationship (Provan and Sydow, 2008). Moreover, measuring and evaluating interorganizational performance is of utmost importance for improving the performance itself and the value created for the end-user (Cepiku, 2017). In fact, the performance resulting from the collaboration between two or more organizations, both in the public and in the private context, is determinant for the performance at the final level.

The high complexity and inter-dependency that characterize inter-organizational contexts entail concerns on how to

The current issue and full text archive of this journal is available on Emerald Insight at: https://www.emerald.com/insight/0885-8624.htm

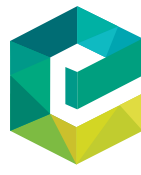

Journal of Business \& Industrial Marketing 36/13 (2021) 15-27

Emerald Publishing Limited [ISSN 0885-8624] [DOI 10.1108/JBIM-07-2020-0353] measure and evaluate the performance of such organizations. Scholars have proposed various ways through which measuring inter-organizational performance, using different concepts and units of analysis, and at the moment, there is no clear identification of the contexts where certain measures of interorganizational performance are more appropriate than others (Provan and Sydow, 2008).

A wide area of research focused on the analysis of performance in inter-organizational contexts, trying to understand the relationship between a set of concepts, such as customer value, service and relationship quality, customer and supplier satisfaction, power, trust, loyalty and so on (among

(C) Lucrezia Coletta, Milena Vainieri, Guido Noto and Anna Maria Murante. Published by Emerald Publishing Limited. This article is published under the Creative Commons Attribution (CC BY 4.0) licence. Anyone may reproduce, distribute, translate and create derivative works of this article (for both commercial and non-commercial purposes), subject to full attribution to the original publication and authors. The full terms of this licence may be seen at http://creativecommons.org/licences/by/4.0/legalcode

Funding details: This research did not receive any specific grant from funding agencies in the public, commercial or not-for-profit sectors.

Received 24 July 2020

Revised 2 November 2020

Accepted 11 December 2020 
others Chumpitaz and Paparoidamis, 2004; Ranaweera and Prabhu, 2003; Rauyruen and Miller, 2007; Selnes, 1998).

In particular, customer value may be considered a key element when approaching the measurement of interorganizational performance. In fact, it can be used as a parameter useful to assess performance (O'Flynn, 2007) in contexts where performance evaluation results rather difficult and complex, such as inter-organizational relationships (Provan and Sydow, 2008). Moreover, customer perceptions on the value of the inter-organizational relationship affect relational aspects (Corsaro and Snehota, 2010), such as intention to continue the relationship.

Scholars have widely analyzed the customer value concept studying both its definitions and link with performance and other dimensions of the inter-organizational relationship.

For example, Hald et al. (2009) proposed a conceptualization for attraction in dyadic business relationships, arguing that three concepts have a key role in developing such relationships, that are value, trust and dependence. Often, the value perceived by the customer is measured by customer satisfaction because it is recognized among scholars as one of the main drivers for consumption behaviors, such as rebuy intention, word-of-mouth or loyalty (Cronin et al., 2000). Another study (Geigenmüller et al., 2012) analyzed the effect of the adoption of customer relationship management practices on customer satisfaction and company performance in business relationships. The findings showed how such practices have positive effects both on customer satisfaction and on organizational performance.

Until now, scholars have deeply analyzed the final customer value in relation to the service received. However, less attention has been given to the understanding of how and to what extent value has been used for performance evaluation in interorganizational contexts. This study aims at filling this gap, by systematizing the scientific knowledge produced from 1991 and 2020. In particular, the literature review refers to the use of the customer value construct for assessing inter-organizational relationship performance, given the centrality of customer value in the measurement of the effectiveness of interorganizational relationships (Cepiku, 2017; Emerson and Nabatchi, 2015). Some literature reviews on customer value and inter-organizational relationships have been conducted by scholars (see among others Ellegaard et al., 2014; Hüttinger et al., 2012; Lindgreen et al., 2012; Tangpong et al., 2015). However, to the best of the authors' knowledge, this study represents the first systematic literature review that provides a classification for customer value and inter-organizational performance measures, also linking the two constructs and discussing possible differences between different settings.

In fact, to make the literature review as more complete as possible and to identify possible differences among different contexts, both public and private literature was included in this study and 1991 was chosen as a suitable starting point able to capture both perspectives. Indeed, from this period, two main events occurred.

First, in 1991 the theorization of the New Public Management (NPM) was proposed by Hood (1991). NPM introduced the idea of the importance of the customer perspective for the evaluation of public services. This was reinforced by the public value paradigm, which considered public value as a multidimensional construct built not only through the final service delivered but also through the interactions occurring during the service delivering and that might generate trust or fairness (O'Flynn, 2005).

Second, on the private side in the same years, servicemarketing researchers began acknowledging the increasing importance of the user in the process of service designing and provisioning (Grönroos, 2006; Reid and Plank, 2000; Vargo and Lusch, 2014; Wieland et al., 2016). They changed the point of view, evolving from the provider perspective to the customer one.

Therefore, scholars widely accepted the importance of customer perspective for enhancing service quality and managerial processes, and therefore, the overall performance of the organization.

Given the huge heterogeneity in the definition of the value dimension and the variety of studies linking customer value to several and different elements of the inter-organizational relationship, the main interest of this study is to understand what kind of customer value has been used and analyzed in relation to performance, and how scholars framed the interorganizational performance dimension.

The rationale for this study is to gather the existing knowledge on inter-organizational performance measured through organizational customer's perspective. Through this study, a bridge between performance measurement in inter-organizational contexts, which pertains to the management field, and customer value, that pertains more to the marketing field, is created. In other words, this study proposes a new perspective of dealing with customer value by linking this long-debated construct to performance measurement in inter-organizational contexts.

It is necessary to clarify that inter-organizational relationships may refer to relationships occurring either between two organizational subjects (dyads) or to more than two subjects (networks). Therefore, for completeness, in addition to the inclusion of public and private literature as previously said, this study also included dyadic and network perspectives, thus comprehending business-to-business (B2B) relationships (dyadic) as well as collaborative governance practices, such as joined-up government, whole-of-government and public networks (Ansell and Gash, 2008; Cepiku, 2017; Provan and Milward, 2001). Starting from the 2000s, network relationships were frequently investigated by scholars, compared to dyadic ones, reflecting the change in the managerial practice.

In fact, given the increasing complexity and interdependency in the environment where the organizations had to work (Ansell and Gash, 2008), collaborative governance practices represented a solution adopted by the organizations themselves to deal with such complexity.

Specifically, through this literature review, the following research questions are addressed:

RQ1. What are the main measures of customer value used by scholars within the inter-organizational relationships context?

RQ2. How did scholars measure performance of interorganizational relationships?

RQ3. Are there any differences in the measures used between public and private contexts or dyadic and service network ones? 
Before continuing with reading, it is necessary to clarify some concepts that will be recurrent hereinafter. Customer value is the central object of interest of this study, together with interorganizational performance, and it is generally defined as a trade-off between benefits and sacrifices perceived by the customer in a supplier's offering (Zeithaml, 1988). Scholars agree that customer value is a cognitive construct, based on a pre-post perspective, which may refer to the present and to the potential customers, and that represents a strategical orientation of the supplier (Eggert and Ulaga, 2002). Whereas, customer satisfaction is a construct often associated with disconfirmation paradigm (Parasuraman et al., 1988), stating that customer satisfaction results from comparing the perceived performance of the supplier and some comparison standards, such as customer expectations. Specifically, the customer is satisfied when he/she perceives the product's performance as equal to the expectations (confirming). Whereas, if the customer perceives a higher or a lower than expected product's performance, he/she is satisfied (positively disconfirming) or dissatisfied (negatively disconfirming). Moreover, differently from customer value, customer satisfaction is an affective construct, based on a post-purchase perspective, that may refer to present customers only, and that represents a tactical orientation of the supplier (Eggert and Ulaga, 2002).

In this study, the concept of inter-organizational performance refers to the evaluation of a professional relationship occurring between two or more subjects, except the final customer.

\section{Methodology}

First, given the abundant concepts investigated in association with customer value as presented in the Introduction, the search strategy was defined also by including the constructs of "user experience" and "satisfaction" as alternatives to the concept of "perceived value." Perceived value was chosen because it is the term that scholars in the marketing field use more frequently when dealing with customer value (SánchezFernández and Iniesta-Bonillo, 2007). The term "satisfaction" was included because even if it is a different concept with respect to value, as discussed in the Introduction, scholars often used it in close connection with customer value. In addition, customer experience is a different construct with respect to customer value, but scholars in the service-marketing field have been using it increasingly in the past years as an evolution of customer satisfaction. In fact, differently from the concept of customer satisfaction that is outcome-oriented, the concept of experience is process-oriented, comprehending all the moments of interactions and emotions during the experience (Schmitt, 1999). Furthermore, the term "collaborative governance" was included because in service network contexts it represents a new and widely diffused tool adopted to improve network performance (Cepiku, 2017).

Given these premises, the research algorithm developed for the systematic literature review was the following: ("perceived value" OR "satisfaction" OR "user experience") AND ("interorganizational” OR “inter-firm” $O R$ "inter-institutional” $O R$ "collaborative governance" OR "business to business" OR "network" OR "partnership") AND ([“evaluation” OR "assessment"] AND “performance”).
The search was focused on papers published from 1991 to 2020 within the Scopus and ISI Web of Science databases; the algorithm was applied to the title, abstract and keywords.

To guarantee transparency and replicability in the methodology, the authors adhered to the "Preferred Reporting Items for Systematic Reviews and Meta-Analyzes" (PRISMA) guidelines (Dekker and Bekkers, 2015; Moher et al., 1996), as indicated in Figure 1.

The papers' search started from 1991 because, as discussed in the Introduction, since 1990s the customer perspective started to be analyzed in connection with value and service and relationship quality, both by the scholars active in the public field and in the private one. In fact, in 1991 the NPM was first theorized by Hood (1991) and during the same years, servicemarketing literature started considering the use of customer experience as a positive factor in the cocreating process with companies (Mustak et al., 2013). Therefore, 1991 was considered the epochal break between a supplier/seller perspective and a user perspective, and consequently, articles published between 1991 and 2020 have been included.

The research has been restricted to papers written in English and published in peer-reviewed journals. In addition, only articles and articles in press were selected, excluding reviews and metaanalyses. Both empirical and theoretical articles, which adopted both a qualitative and quantitative method, are considered. Then, no additional filter was introduced on these points.

After the removal of duplicates (101), the output consisted of 1,303 documents, of which 730 papers from Scopus and 594 papers from ISI Web of Science. The authors proceeded with the 1,303 abstract skimming based on titles and abstracts, to determine whether they should be included in the full textreading step. In the first step, the following were excluded:

- articles that did not focus on inter-organizational contexts and did not discuss concepts of value, meant as a wide concept (for example, comprehending also concepts such as customer satisfaction and quality); and

- articles not belonging to the management or public policy fields, thus papers that adopted an engineering approach or method were excluded.

The selection process was double-checked by the authors, who discussed divergent coding and reached a common decision. This process reduced the sample to 145 articles that were read in full text during the second step.

As in the previous step, the inclusion criteria concerned the focus on inter-organizational contexts (either dyadic or network cases) and the use of value for assessing the inter-organizational performance. Papers dealing with final customer value were included only if this was informative about the interorganizational performance. The main reasons for exclusions were not dealing with inter-organizational relationships; not dealing with user value; not dealing with inter-organizational performance; not clear in terms of methodology or concepts used; and not available in English or in full text. After this stage, the full texts selected for the analysis were 41 . Figure 1 reports the PRISMA diagram describing the selection process.

For these papers, the authors coded articles considering, in addition to citation information (e.g. year of publication, journal, authors), the following issues: article type (empirical or theoretical); sector (private, public or public-private 
Figure 1 PRISMA flow diagram

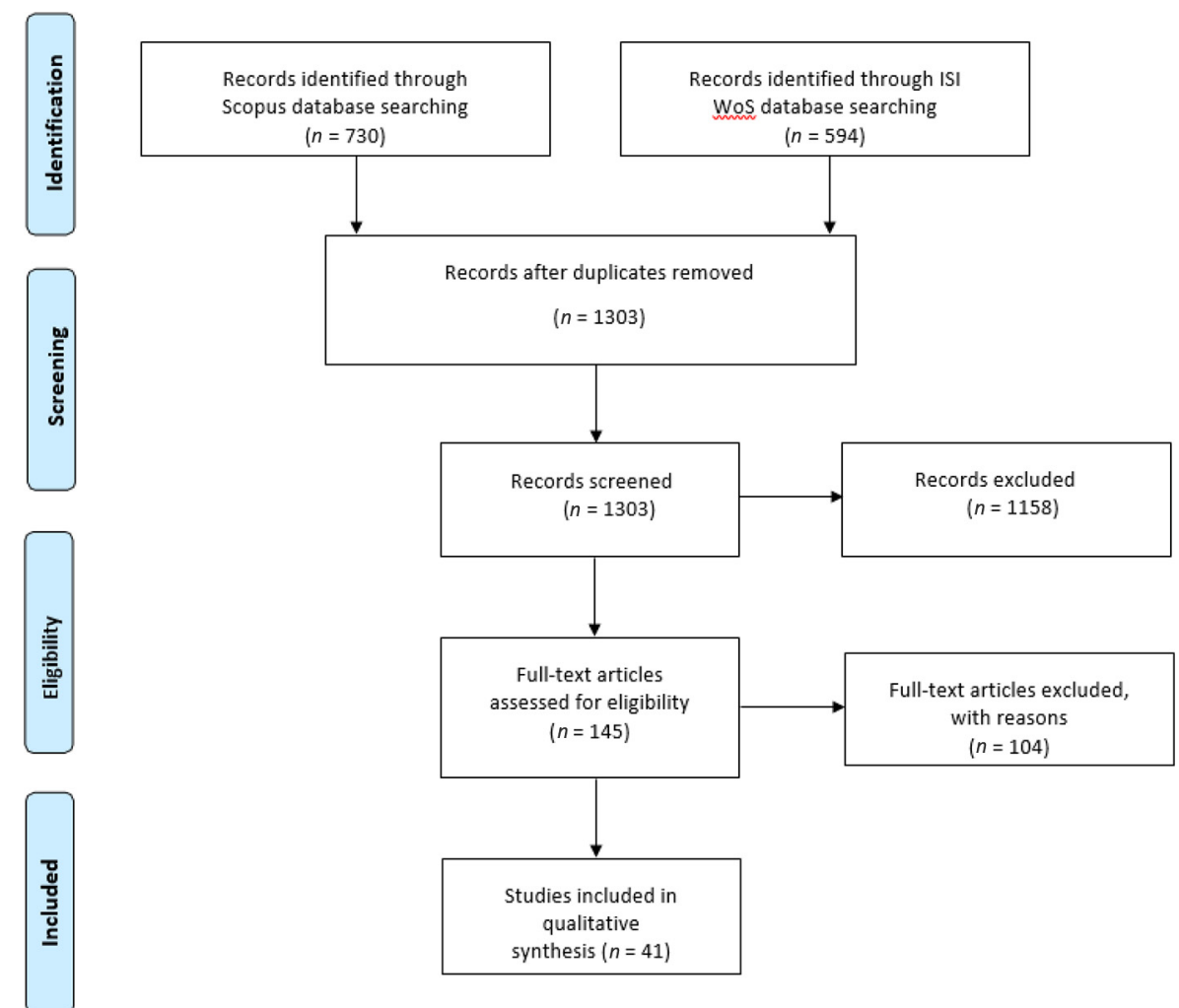

partnership [PPP]); the method of analysis (e.g. case study, survey); the country of the study; industry (e.g. health, restaurant, etc.); the dimension of value analyzed; if the performance evaluation was systematic or una tantum; and research questions and main findings. Notes fields were used to add additional relevant information. The full classification of the articles included in this study is reported in Table A1 of the Appendix.

\section{Results}

First, a synthesis of the main features of the articles included in the systematic review $(n=41)$ is provided. The papers were equally divided among the adoption of a dyadic perspective and a service network perspective, although it is interestingly noticing that a dyadic perspective was adopted mainly in the first period of analysis, while since 2010, scholars started adopting a network perspective. This is coherent with the increasing academic and managerial interest in collaborative governance arrangements that started since the 21 st century. Most papers focused on the private sector and the most investigated fields were the health-care sector, the construction and manufacturing industries.

In the following paragraphs, the three research questions stated in the Introduction are addressed.

\section{Conceptualization of value in the inter-organizational contexts}

As discussed in the Introduction, customer value is a concept widely investigated by scholars and at the same time highly debated in terms of meaning and attributes. For this reason, researchers have tried analyzing it in relation with other concepts, such as quality, individual behaviors (e.g. willingness to recommend or intention to repurchase), relational features (e.g. trust, power, cooperation) and service features (e.g. lead time, timely delivery, cost). For what concerns the interorganizational context, by answering the first research question, the systematic literature review revealed that customer value has been investigated through five main perspectives: value as a net benefit (traditional perspective), value as a service-related construct, value as a relationship-related construct, value as customer satisfaction and value as knowledge sharing. Often, scholars used more than one perspective to define customer value, as shown in Figure 2, which summarizes the measures of value found in the literature.

\section{Value as a net benefit}

In this study, only two articles were found to adopt the traditional perspective of value as a net benefit, i.e. as a "tradeoff between benefits and sacrifices" (Zeithaml, 1988). In particular, Olaru et al. (2008) focused on an R\&D service and framed the sacrifices in terms of monetary expenditure and time, and the benefits in terms of relationship and service quality. Luu et al. (2016) investigated B2B relationships in a transportation and logistics service, and defined value through two different perspectives, process value and outcome value. In the process value, benefits were measured as the positive experience perceived by the customers during the service process, while in the outcome value benefits related to the positive experience the customers perceive when the service 
Figure 2 Conceptualization of customer value in inter-organizational contexts

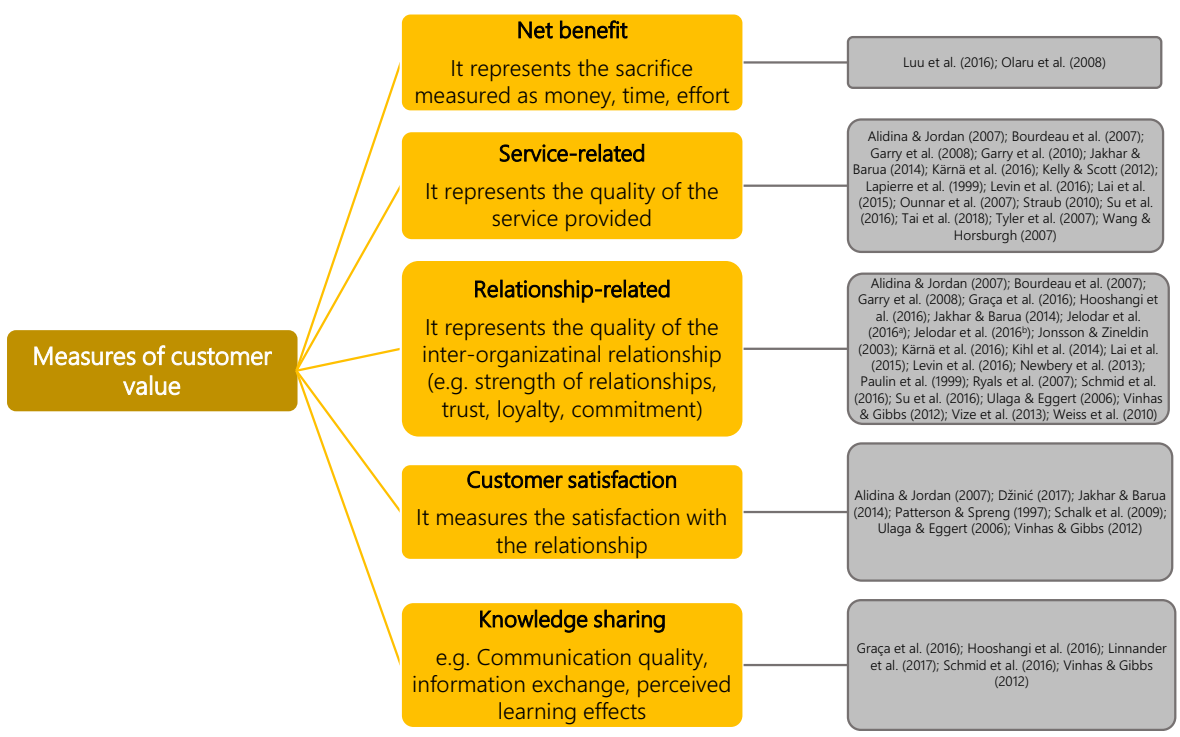

ends. Sacrifices were defined uniquely, i.e. as a multidimensional concept composed of money, time and effort.

It is interesting that only two articles used the traditional definition of customer value in relation to inter-organizational relationships. This result suggests that other conceptualizations of customer value were found more appropriate by scholars to investigate the inter-organizational context, at least staring from the 1990s.

\section{Value as a service-related construct}

Many scholars agree on the service-related nature of customer value. For example, Tyler et al. (2007) focused on a B2B service and analyzed the relationship between service quality, customer satisfaction and retention of different customers' typologies. In particular, they were interested in understanding the potential negative asymmetries generated by the effect of service quality on the other two dimensions. A negative asymmetry occurs when a lower than average service quality perception impacts more intensively on customer satisfaction and retention than a higher than average perception. The authors defined service quality as composed by service outcome, technical quality and functional quality. They found that for large companies, service outcome can be considered the principal determinant for customer satisfaction, with a significant negative asymmetric effect. However, for small companies, reliability and functional quality show a strong positive impact on continuance intentions, with a negative asymmetry. Kelly and Scott (2012) aimed at understanding the benefits valued by the customer in a B2B setting and they concluded that among these benefits one can find service benefits characterized as those designed to improve service delivery. Another study by Tai et al. (2018) focused on the health-care sector and discussed quality outcomes in connection with patient satisfaction. In this case, the quality outcome was categorized as a concept corresponding to the service quality discussed in the private literature. This study is particularly interesting because it is one of the few papers introducing the concept of the importance of final customers' perceptions for the evaluation of inter-organizational performance. In other words, it proposes that the good functioning of the service network can be assessed also through the final customer perspective, in addition to the satisfaction of the actors operating within the network.

Value as a relationship-related construct

Most articles attributed some relationship-related features to value. This perspective includes all definitions of value that are linked to what occurs before the service delivery. In other words, the constructs belonging to this category can be considered facilitators for the maintenance of a long-term interorganizational relationship. In fact, the main attributes of the relationship-related constructs dealt with relationship strength, trust, commitment and loyalty. Jonsson and Zineldin (2003) investigated how to develop and maintain solid and continuative business relationships between suppliers and sellers, and defined value as determined by close and positive relationships. Graça et al. (2016) analyzed relational benefits considering three different dimensions, i.e. functional, psychological and social one, to understand how the institutional setting of an emerging market affects the assessment procedure and governance system. The authors framed value both as a multidimensional relational concept comprising trust, social benefits and communication quality and as a service-related concept (functional benefits). They concluded that buyers of emerging markets consider relationalbased benefits as more valuable than functional benefits, while for buyers of high-income countries, the opposite holds. Paulin et al. (1999) postulated that strong relationships are fundamental to foster inter-organizational performance. Ulaga and Eggert (2006) defined relationship quality as composed by different elements, i.e. trust, commitment and satisfaction; and relationship value as an antecedent to relationship quality and behavioral outcomes. Jelodar et al. (2016a) identified three principal attributes of relationship quality, that are trust, commitment and teamwork, whose main components are 
communication and cooperation. Using the same conceptualization of value, Jelodar et al. (2016b) determined how parties less experienced tend to use more the concept of trust as a measure of relationship quality, whereas more experienced parties tend to look at more tangible measures to evaluate relationship quality. Finally, Parast (2019) analyzed the relationship between some measures of quality for supply chain management and supply chain performance. They hypothesized and tested that trust has a positive effect on information sharing, process improvement, supply chain satisfaction and supply chain performance.

\section{Value as customer satisfaction}

A group of scholars conceptualized customer value as a dimension gathered by satisfaction. In particular, some articles dealt with the concept of satisfaction with the relationship (Schalk et al., 2009; Ulaga and Eggert, 2006; Vinhas and Gibbs, 2012). In these cases, authors considered relationship quality dimension only, rather than also service quality dimension. Coherently, as stated by Nzekwe-Excel et al. (2010), understanding the values composing the broad concept of customer satisfaction and enhancing the collaboration among the parties can be a way to improve customer satisfaction itself. Buchan et Yates (2019) analyzed a UK regional coastal partnership looking at the members' perceptions about the purpose of the partnership and their level of satisfaction with the partnership performance.

\section{Value as knowledge sharing}

Another interesting conceptualization of value deals with the idea of information or knowledge sharing. In fact, as also evidenced in a study by Mahama (2006), information sharing is positively associated with performance, even if only indirectly. Vinhas and Gibbs (2012) considered information exchange as a determinant of relationship outcome. Whereas, Linnander et al. (2017) studied an association specifically established to increase the supply of medical provision in Tanzania through the knowledge transfer from Coca-Cola to Tanzania's Medical Stores Department. Then, they framed value based on participants' evaluation of the process of knowledge transfer. Schmid et al. (2016) focused on climate change and analyzed 16 innovative partnerships created based on some policy reforms. They framed the success of network cooperation as a three-dimensional measure, comprehending satisfaction with cooperation, perceived learning effects and perceived implementation capacity. They highlighted the importance of an appropriate information management for a good network performance. Discordant results for the manufacturing sector were evidenced in a study by Hooshangi et al. (2016), who did not find significant positive effects of information sharing on buyer satisfaction.

\section{Conceptualization of inter-organizational performance}

The understanding of how scholars framed inter-organizational performance represents the aim of the second research question of this study.

The review evidenced how inter-organizational performance has been defined in two conceptually different ways. From one side, some scholars defined inter-organizational performance as perfectly corresponding to the customer value. In other words, they used customer value as a proxy for the performance of the dyadic or network relationship. This conceptualization of performance has been applied mostly to service network contexts rather than dyadic ones (Table A1 of the Appendix). In addition, proportionally this conceptualization of performance was found mainly in articles where value was framed as a service-related construct or as customer satisfaction. For instance, Schmid et al. (2016) analyzed the determinants of networks' collaboration success relative to policy-induced innovation on climate change adaptation. They framed network performance as the network collaboration success that was defined as a three-dimensional metric comprehending satisfaction with cooperation, perceived learning effects and perceived implementation capacity. They highlighted the importance of repeated participation, i.e. significant involvement in the network, adequate information sharing and inclusive and accountable network activities. Alidina and Jordan (2007) proposed an evaluation framework for the Child Health Network and adopted a multidimensional perspective of performance, which was the result of patient satisfaction, effectiveness, integration, accessibility, accountability, affordability and appropriate care. This contribution represents another attempt to evaluate network performance through the final customer perspective. Jakhar and Barua (2014) developed an evaluation model for assessing the sustainability performance in the textile sector and they identified delivery and logistic performance (value as a servicerelated construct) and customer service and satisfaction performance (value as customer satisfaction) among the dimensions constituting the multidimensional performance framework. Finally, Leksono et al. (2019) developed a healthcare supply chain performance-measurement system, considering several perspectives and measures as performance indicators, such as service quality, knowledge sharing and customer satisfaction. They showed that the customer perspective plays the main role in determining supply chain performance.

In contrast, the second stream of research treated interorganizational performance and customer value as two different concepts. The main measures used for defining interorganizational performance were the following: customer satisfaction, which was the measure most frequently used by scholars, loyalty, relationship quality, operating performance and rebuy/reuse intentions (Figure 3).

Wang and Horsburgh (2007) focused on large airline alliances and analyzed the relationship between service network coherence, customer satisfaction and market-based performance indicators. In this analysis, customer value was captured by service quality and the network performance was assessed through customer satisfaction. As the other examples aforementioned, this study represents an attempt to evaluate the network performance through the final customer perspective. Newbery et al. (2013) investigated the performance of professional partnerships in rural agreements and used partners' satisfaction and willingness to pay as two measures of performance. An interesting finding is that partnerships were considered more valuable in centers with a lower level of trust. Weiss et al. (2010) considered six publichealth associations dealing with breast cancer screening and analyzed the role of leadership and management. They adopted members' satisfaction as a measure of inter-organizational 
Figure 3 Conceptualization of inter-organizational performance and associated measures of customer value

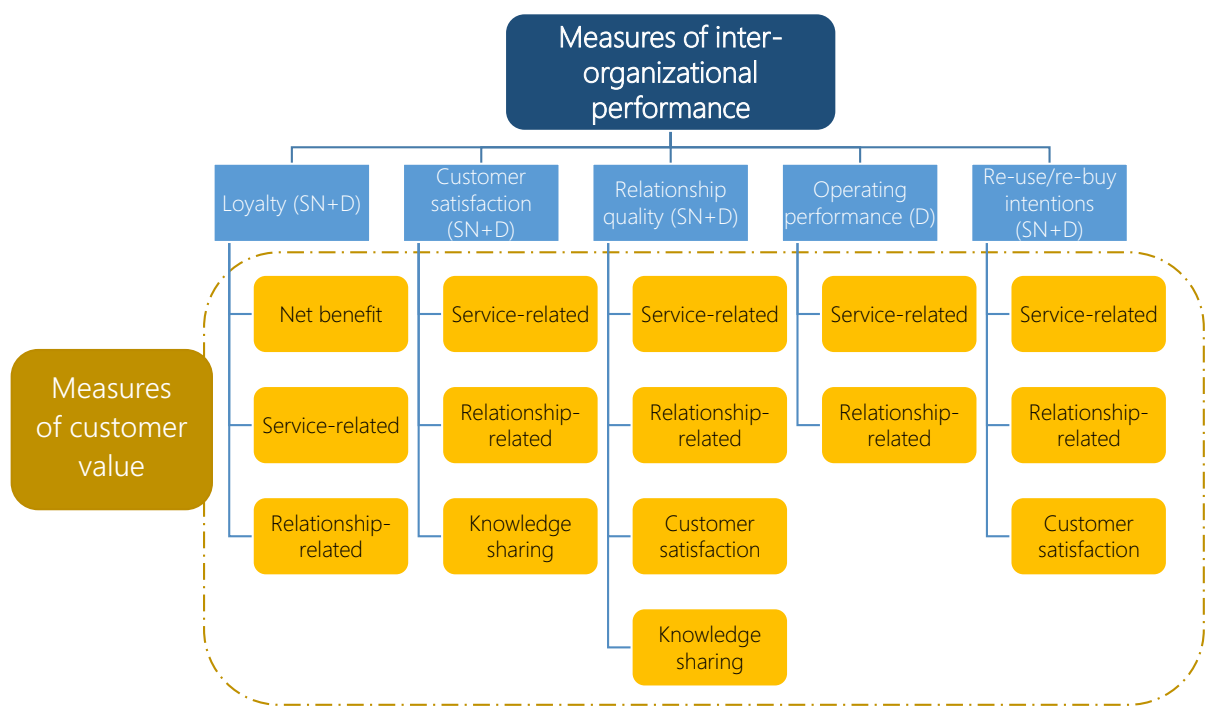

performance, whereas customer value was captured by partners' involvement. The results showed a positive correlation between partners' involvement and their satisfaction with the partnership, thus confirming the association between relationship quality and customer satisfaction. The use of customer satisfaction emerged from the studies discussed earlier is recurrent in the literature, since the satisfaction of a party with the performance of other parties can be considered a proxy for the success of a relationship (Lehtiranta et al., 2012).

Other authors defined performance through other measures. For example, Levin et al. (2016) analyzed the effect of creative capabilities and project management on the long-term relationship between a customer and an advertising agency. They discovered that relationship quality (measured by trust) is crucial for enhancing the relationship between the two parties and the continuance of B2B relationships. Luu et al. (2016) compared the impacts of process value and outcome value on relationship intensity, and they had evidence on how the impact of process value on relationship intensity was higher than that of outcome value. An example of performance measured through rebuy intentions is the work by Patterson and Spreng (1997). They investigated how value, satisfaction and rebuy behaviors were related to a B2B professional service. They determined that satisfaction mediates the relationship between perceived value and rebuy behaviors that were considered a measure of performance. To conclude, an interesting paper (Lai et al., 2015) focused on the relationship between a supplier and an overseas distributor and proposed a system able to measure the creation of value. The authors considered performance as a more objective measure, i.e. operating performance, assessing a positive relationship between six factors pertaining to relationship value and operating performance.

Figure 3 shows the measures used to define interorganizational performance and the measures of customer value that scholars used in relation to them, in case these were not coincident. For each measure of performance, it is specified the context where that measure has been used: service network (SN), dyadic (D) or both. This specification will be discussed in the next paragraph.

\section{Differences among private and public contexts and dyadic and network settings}

The third research question was about understanding possible differences in the conceptualization of customer value and inter-organizational performance, depending on the context (i.e. public vs private or dyadic vs network). The first result emerging from the analysis and shown in Figure 3 and in Table A1 of the Appendix, is that scholars have treated customer value and inter-organizational performance differently for dyadic and network relationships. For example, network studies defined more frequently than dyadic ones the inter-organizational performance directly through the customer value.

Then, relationship quality as a measure of performance is used along with any construct of customer value, and independently from the context considered (dyadic or network). Whereas, operating performance as a measure of performance has been used only in dyadic settings and has been used only when customer value was framed either as a service or as a relationship-related construct.

Moreover, the review evidenced a main distinction between dyadic and network settings based on the purposes behind the measurement of inter-organizational performance.

In fact, for what concerns the dyadic setting, scholars primarily investigated the relationship between quality, value and behavioral outcomes, such as rebuy intentions, loyalty or willingness to pay. Those papers aimed at understanding the antecedents of customer value and relating them to interorganizational performance, mainly measured by either customer satisfaction or behavioral intentions. The final purpose was to improve performance or to foster the continuity of the long-term relationships by acting on customer value improvement. For instance, Lapierre et al. (1999) focused on how organizational customers assess professional service, 
analyzing the effects of quality, value and satisfaction on users' intents to purchase engineering services. Results showed that value influence satisfaction, while purchase (or repurchase) behaviors depend on satisfaction. Kelly and Scott (2012) were interested in understanding what are the benefits valued by customers in a B2B setting. Relationship benefits had positive indirect effects on commitment, absence of conflict and satisfaction and a negative association with switching intentions.

In contrast, studies with a $\mathrm{SN}$ perspective were more focused on the use of value for the evaluation of the success or effectiveness of a certain program, project or partnership. For instance, Doloi (2012) proposed an evaluation framework suitable for assessing how public infrastructure initiatives performed from a social perspective and the amount of value generated, also combined the degree of stakeholders' involvement with the social perceived value. Kärnä and Junnonen (2016) focused on projects of construction and developed a benchmarking mechanism, consisting of an evaluation system able to assess the performance of a project where several companies participated. Some performance measures concerned goal achievement and stakeholders' participation. Moreover, the authors highlighted the need to select subcontractors who distinguish their know-how and capability to deliver service quality. In fact, subcontractors are selected mainly considering the price, while expertise is not taken enough into consideration. Buchan and Yates (2019) analyzed the stakeholders' perception about the purposes of a UK regional coastal partnership, showing that its purpose was well understood and highly shared among the stakeholders. Finally, a PPP example is represented by Sutherland's work (2017) that developed a multidimensional tool to assess the effective management of drinking-water supply.

Finally, no significant difference was found between public and private contexts in terms of conceptualization of customer value or inter-organizational performance.

Table A1 of the Appendix reports the complete classification of the articles included and discussed in this study.

\section{Discussion}

The first observation is related to the high number of papers that were excluded in the abstract skimming phase (Figure 1). Papers were excluded because they did not focus on interorganizational contexts and/or on value and did not belong to the management or public policy fields. This result means that there is not much attention on this specific topic.

The first evidence emerged from the systematic analysis of the articles confirms what discussed in the Introduction, i.e. that the construct of value has been framed in several ways. In the service-marketing literature, value has traditionally been conceptualized as a "trade-off between benefits and sacrifices" (Zeithaml, 1988), i.e. as:

[...] the perceived worth in monetary units of the set of economic, technical, service, and social benefits received by a customer firm in exchange for the price paid for a product offering, taking into consideration the available alternative suppliers offerings and prices' (Anderson, 1995).

In the study, only two papers were found to adopt this traditional definition of value, while most scholars overcame this definition and adopted a perspective comprehending service and relationship features, customer satisfaction and knowledge sharing. This finding suggests that in interorganizational contexts, scholars found more appropriate to use different measures of customer value with respect to its traditional definition.

Then, some overlaps between the concept of value and one of inter-organizational performances were also found. For example, customer satisfaction is sometimes used as a proxy for value (among others Džinić, 2017; Patterson and Spreng, 1997; Schalk et al., 2009) and other times as a proxy for interorganizational performance (among others Garry et al., 2010; Newbery et al., 2013; Tyler et al., 2007). In some studies, satisfaction is also framed as a constituent of relationship outcome or otherwise as related to relationship quality (Ulaga and Eggert, 2006; Vinhas and Gibbs, 2012).

Another finding is that inter-organizational performance was framed mainly through two different approaches. Some authors measured inter-organizational performance directly through the measure of customer value (among others Jakhar and Barua, 2014; Kärnä and Junnonen, 2016; Linnander et al., 2017; Ounnar et al., 2007), while other scholars distinguished between the two concepts (among others Bourdeau et al., 2007; Hooshangi et al., 2016; Levin et al., 2016; Paulin et al., 1999). The first approach was frequently used in SN settings rather than in dyadic ones. The main measures of inter-organizational performance, when not coinciding with customer value, were relationship quality, customer satisfaction, loyalty, operating performance and rebuy/reuse intentions.

An interesting result found in a paper by Luu et al. (2016) evidenced how the impact of process value on relationship intensity was higher than that of outcome value. This finding is coherent with Grönroos (2001) who framed service quality as a two-dimensional construct, composed of technical and functional quality. Technical quality is the result of the service delivery procedure, and it corresponds to what the user owns at the end of this procedure. Whereas, functional quality refers to the process through which the technical quality is transmitted to the customer, and this is strictly related to the customer experience.

Results also showed that some measures of performance were used independently from the setting and concept of value adopted, such as the case of customer satisfaction, which is also one of the main preferred measures of interorganizational performance. In other cases, the choice of a certain measure of performance is more dependent on the setting and is associated with the specific concept of value. For example, operating performance was used especially along with service or relationship-related constructs and was used only in dyadic contexts. Another difference between dyadic and network relationships concerned the purpose of measuring the inter-organizational performance. In fact, in dyadic settings, the goal of this evaluation seemed to be the enhancement of partners' value, with a positive consequence on their mutual satisfaction with the other party's performance, and finally on behavioral intentions, such as repurchasing and continuance of the $\mathrm{B} 2 \mathrm{~B}$ relationship. In contrast, in SN settings, scholars were more interested in developing an evaluation framework able to assess the interorganizational performance, meant as a broad concept also 
comprehending social and environmental sustainability. Other purposes regarded the effectiveness of the implementation of projects, programs, partnerships or the success of the collaboration. Whereas, no significant difference was found between public and private contexts.

Another interesting result is that some scholars not only investigated inter-organizational relationships, but they also considered the final customer perspective as a precious source of information able to assess inter-organizational performance. Some examples were found in the public sector, such as the health-care sector, where the patients were called to evaluate the effectiveness or the outcomes of a particular health program (Alidina and Jordan, 2007; Sutherland, 2017; Tai et al., 2018) and the education sector (Schalk et al., 2009). However, some examples were also found in the private sector, especially concerning transportation services (Bourdeau et al., 2007; Wang and Horsburgh, 2007). The idea of using the final customer point of view for the evaluation of interorganizational performance is a new and interesting perspective in service and relationship marketing research since it recognizes that what happens between two or more organizations will be spilled over the final user. Therefore, the final user can be able not only to evaluate the interorganizational performance, but she/he can also represent a fundamental source of information for improving that performance.

Another finding is that some scholars conceptualized value in business relationships as the knowledge shared between the parties. This conceptualization of value was found in studies focused on relationship marketing and quality, with the idea that inter-organizational relationships reduce potential opportunistic behaviors by one of the parties, also improving the flow of information between them (Corsaro and Snehota, 2010).

The last observation is that, coherently with what is found by Dekker (2016), several articles included in this review investigated inter-organizational performance considering the perspective of only one side of the relationship. Whereas, it would be desirable to build a multifaceted framework for the evaluation of a certain inter-organizational relationship through the different values of all parties involved in the relationship. In fact, there may be relevant differences in how different parties perceive the value of their reciprocal relationship (Corsaro and Snehota, 2010).

\section{Conclusions and future research}

To the best of the authors' knowledge, this review represents the first attempt to systematize the literature about the use of customer value for performance evaluation in interorganizational contexts. The aim of this study, and one of its main contributions, is to propose a new perspective when dealing with customer value, by linking this concept to interorganizational performance measurement. By doing so, the construct of customer value is investigated in a managerial manner, allowing for practical and managerial conclusions.

The main contributions of this study are providing a categorization for the concepts of customer value used in interorganizational contexts, for the measures of interorganizational performance, and a discussion on the main differences between different settings, namely, dyadic and network relationships.

Nowadays, in contexts characterized by high intensity of relationships, high inter-dependency and high fragmentation (features especially relevant in networks), scholars and practitioners must face difficulties in measuring interorganizational performance. This occurs both in the public and in the private context, both in a dyadic and in SN setting. One possibility to deal with this difficulty is measuring interorganizational performance through the value perceived by customers.

This systematic literature represents a starting point for both scholars and practitioners, who are dealing with complex interorganizational contexts and are interested in acquiring comprehensive knowledge on how previous scholars have defined and evaluated inter-organizational performance using different concepts of value, depending on the setting (D vs $S N$ ).

Also, considering the recent calls on the importance of using measures of customer value for assessing and analyzing interorganizational performance (Bititci et al., 2012; Cepiku, 2017), from this study some room for future research emerged.

First, future research could focus on the design of frameworks suitable for a continuative and systematic evaluation of inter-organizational performance. In fact, most studies did not describe nor develop a systematic framework on the use of customer value to assess inter-organizational performance; rather they conducted some empirical analyses on a specific and circumscribed case study.

The second suggestion is to further develop the approach followed by some scholars who considered the final customer value as informative on the performance of the interorganizational performance. This represents an interesting and innovative avenue of research, which may investigate how and to what extent organizational value is correlated with final customers' one, and how both forms of value are related to objective measures of performance.

A third recommendation, as also suggested by Dekker (2016) and confirmed by the findings of this review, concerns the need for developing performance evaluation frameworks able to consider and combine different values of different subjects involved in the relationship. Clearly, this goal is less complex for dyadic relationships and becomes more and more challenging for network relationships.

Finally, as emerged from this study, some scholars used knowledge sharing as a measure for customer value. This a recent and new way to define customer value compared to other traditional and deeply investigated concepts, such as relationship and service quality or customer satisfaction. Therefore, it would be interesting to extend the research on the role of knowledge sharing as a proxy for evaluating the inter-organizational performance, to understand whether it may apply to any context or to certain settings only.

A limitation related to this study relates to the choice of the keyword on the performance evaluation. In particular, given the fact that performance is a multidimensional concept that may be measured through several indicators, some articles that used other terminology or specific indicators instead of the broader term "performance" may have been missed in the review. 


\section{References}

Alidina, S. and Jordan, M. (2007), "The challenges of evaluating health systems networks: lessons learned from an early evaluation of the child health network for the greater Toronto area", Healthcare Management Forum, Sage CA: Los Angeles, CA: SAGE Publications, Vol. 20 No. 2, pp. 22-27.

Anderson, J.C. (1995), "Relationships in business markets: exchange episodes, value creation, and their empirical assessment", Fournal of the Academy of Marketing Science, Vol. 23 No. 4, p. 346

Ansell, C. and Gash, A. (2008), "Collaborative governance in theory and practice", Fournal of Public Administration Research and Theory, Vol. 18 No. 4, pp. 543-571.

Bititci, U., Garengo, P., Dörfler, V. and Nudurupati, S. (2012), "Performance measurement: challengesfor tomorrow", International fournal of Management Reviews, Vol. 14 No. 3, pp. 305-327.

Bourdeau, B.L., Cronin, J.J., Jr, and Voorhees, C.M. (2007), "Modeling service alliances: an exploratory investigation of spillover effects in service partnerships", Strategic Management Fournal, Vol. 28 No. 6, pp. 609-622.

Buchan, P.M. and Yates, K.L. (2019), "Stakeholder dynamics, perceptions and representation in a regional coastal partnership", Marine Policy, Vol. 101, pp. 125-136.

Cepiku, D. (2017), “Collaborative governance”, in Klassen, T, Cepiku, D, Lah TJ. (Eds), The Routledge Handbook of Global Public Policy and Administration, The Routledge.

Chumpitaz, R. and Paparoidamis, N.G. (2004), "Service quality and marketing performance in business-to-business markets: exploring the mediating role of client satisfaction", Managing Service Quality: An International fournal, Vol. 14 Nos 2/3, pp. 235-248.

Corsaro, D. and Snehota, I. (2010), "Searching for relationship value in business markets: are we missing something?", Industrial Marketing Management, Vol. 39 No. 6, pp. 986-995.

Cronin, J.J., Jr, Brady, M.K. and Hult, G.T.M. (2000), "Assessing the effects of quality, value, and customer satisfaction on consumer behavioral intentions in service environments", fournal of Retailing, Vol. 76 No. 2, pp. 193-218.

Dekker, H.C. (2016), "On the boundaries between intrafirm and interfirm management accounting research", Management Accounting Research, Vol. 31, pp. 86-99.

Dekker, R. and Bekkers, V. (2015), "The contingency of governments' responsiveness to the virtual public sphere: a systematic literature review and Meta-synthesis", Government Information Quarterly, Vol. 32 No. 4, pp. 496-505.

Doloi, H. (2012), “Assessing stakeholders' influence on social performance of infrastructure projects”, Facilities, Vol. 30 Nos 11/12, pp. 531-550.

Džinić, J. (2017), "Effective implementation of a quality management policy in public administration: experiences from Spain and lessons for Croatia", Hrvatska $i$ Komparativna Javna Uprava, Vol. 17 No. 4, pp. 639-664.

Eggert, A. and Ulaga, W. (2002), "Customer perceived value: a substitute for satisfaction in business markets?”, fournal of Business E Industrial Marketing., Vol. 17 Nos 2/3.
Ellegaard, C., Medlin, C.J. and Geersbro, J. (2014), "Value appropriation in business exchange-literature review and future research opportunities", fournal of Business $\mathcal{E}$ Industrial Marketing, Vol. 29 No. 3.

Emerson, K. and Nabatchi, T. (2015), Collaborative Governance Regimes, Georgetown University Press.

Garry, T. (2008), "Affect and the role of corporate customer expertise within legal services", fournal of Services Marketing, Vol. 22 No. 4, pp. 292-302.

Garry, T., Melewar, T.C., Wright, L.T. and Jayawardhena, C. (2010), "The impact of service encounter quality in service evaluation: evidence from a business-to-business context", Fournal of Business $\mathcal{E}$ Industrial Marketing.

Geigenmüller, A., Ata, U.Z. and Toker, A. (2012), "The effect of customer relationship management adoption in businessto-business markets", fournal of Business \& Industrial Marketing.

Graça, S.S., Barry, J.M. and Doney, P.M. (2016), "B2B commitment building in emerging markets: the case of Brazil", Fournal of Personal Selling \& Sales Management, Vol. 36 No. 2, pp. 105-125.

Grönroos, C. (2001), "The perceived service quality concept a mistake?", Managing Service Quality: An International fournal, Vol. 11 No. 3, pp. 150-152.

Grönroos, C. (2006), "Adopting a service logic for marketing”, Marketing Theory, Vol. 6 No. 3, pp. 317-333.

Hald, K.S., Cordón, C. and Vollmann, T.E. (2009), “Towards an understanding of attraction in buyer-supplier relationships", Industrial Marketing Management, Vol. 38 No. 8, pp. 960-970.

Hood, C. (1991), "A public management for all seasons?", Public Administration, Vol. 69 No. 1, pp. 3-19.

Hooshangi, M., Fazli, S. and Mirhosseini, S.S. (2016), "The mediation role of buyer's satisfaction in relationship between structural capital with performance", International fournal of Logistics Systems and Management, Vol. 23 No. 3, pp. 329-342.

Hüttinger, L., Schiele, H. and Veldman, J. (2012), "The drivers of customer attractiveness, supplier satisfaction and preferred customer status: a literature review", Industrial Marketing Management, Vol. 41 No. 8, pp. 1194-1205.

Jakhar, S.K. and Barua, M.K. (2014), “An integrated model of supply chain performance evaluation and decision-making using structural equation modelling and fuzzy AHP”, Production Planning E Control, Vol. 25 No. 11, pp. 938-957.

Jelodar, M.B., Yiu, T.W. and Wilkinson, S. (2016a), "A conceptualisation of relationship quality in construction procurement", International Fournal of Project Management, Vol. 34 No. 6, pp. 997-1011.

Jelodar, M.B., Yiu, T.W. and Wilkinson, S. (2016b), "Assessing contractual relationship quality: study of judgment trends among construction industry participants", fournal of Management in Engineering, Vol. 33 No. 1, p. 04016028

Jonsson, P. and Zineldin, M. (2003), “Achieving high satisfaction in supplier-dealer working relationships. Supply chain management", An International fournal, Vol. 8 No. 3, pp. 224-240.

Kärnä, S. and Junnonen, J.M. (2016), "Benchmarking construction industry, company and project performance by 
participants' evaluation", Benchmarking: An International Fournal, Vol. 23 No. 7, pp. 2092-2108.

Kelly, S. and Scott, D. (2012), "Relationship benefits: conceptualization and measurement in a business-tobusiness environment", International Small Business fournal: Researching Entrepreneurship, Vol. 30 No. 3, pp. 310-339.

Kihl, L.A., Tainsky, S., Babiak, K. and Bang, H. (2014), "Evaluation of a cross-sector community initiative partnership: delivering a local sport program", Evaluation and Program Planning, Vol. 44, pp. 36-47.

Lai, C.S., Chan, D.Y.C., Yang, C.F. and Hsu, W.C. (2015), "The value creation scale of supplier-distributor relationship in international markets", Fournal of Business E Industrial Marketing, Vol. 30 No. 2, pp. 171-181.

Lapierre, J., Filiatrault, P. and Chebat, J.C. (1999), "Value strategy rather than quality strategy: a case of business-tobusiness professional services", Fournal of Business Research, Vol. 45 No. 2, pp. 235-246.

Lehtiranta, L., Kärnä, S., Junnonen, J.M. and Julin, P. (2012), "The role of multi-firm satisfaction in construction project success", Construction Management and Economics, Vol. 30 No. 6, pp. 463-475.

Leksono, E.B., Suparno, S. and Vanany, I. (2019), "Integration of a balanced scorecard, DEMATEL, and ANP for measuring the performance of a sustainable healthcare supply chain", Sustainability, Vol. 11 No. 13, p. 3626.

Levin, E., Thaichon, P. and Quach, T.N. (2016), "The impact of creative competence and project management on longevity of the client-advertising agency relationship", Fournal of Business \& Industrial Marketing, Vol. 31 No. 2, pp. 274-286.

Lindgreen, A., Hingley, M.K., Grant, D.B. and Morgan, R.E. (2012), "Value in business and industrial marketing: past, present, and future", Industrial Marketing Management, Vol. 41 No. 1, pp. 207-214.

Linnander, E., Yuan, C.T., Ahmed, S., Cherlin, E., TalbertSlagle, K. and Curry, L.A. (2017), "Process evaluation of knowledge transfer across industries: leveraging Coca-Cola's supply chain expertise for medicine availability in Tanzania", PloS One, Vol. 12 No. 11, p. e0186832

Luu, N., Hau, L.N., Ngo, L.V., Bucic, T. and Cuong, P.H. (2016), "Outcome versus process value in service delivery", Fournal of Services Marketing, Vol. 30 No. 6, pp. 630-642.

Mahama, H. (2006), "Management control systems, cooperation and performance in strategic supply relationships: a survey in the mines", Management Accounting Research, Vol. 17 No. 3, pp. 315-339.

Moher, D., Altman, D.G. and Tetzlaff, J. (1996), "PRISMA (preferred reporting items for systematic reviews and metaanalyses)", Guidelines for Reporting Health Research: A User's Manual, 1999, Vol. 250.

Mustak, M., Jaakkola, E. and Halinen, A. (2013), "Customer participation and value creation: a systematic review and research implications", Managing Service Quality: An International fournal, Vol. 23 No. 4, pp. 341-359.

Newbery, R., Sauer, J., Gorton, M., Phillipson, J. and Atterton, J. (2013), "Determinants of the performance of business associations in rural settlements in the United Kingdom: an analysis of members' satisfaction and willingness-to-pay for association survival", Environment and Planning A: Economy and Space, Vol. 45 No. 4, pp. 967-985.

Nzekwe-Excel, C., Nwagboso, C., Georgakis, P. and Proverbs, D. (2010), "Integrated framework for satisfaction assessment in construction sector", fournal of Engineering, Design and Technology, Vol. 8 No. 2, pp. 168-188.

O’Flynn, J. (2005), “A public value framework for contractual governance. PUBLIC, issue”.

O'Flynn, J. (2007), "From new public management to public value: paradigmatic change and managerial implications", Australian fournal of Public Administration, Vol. 66 No. 3, pp. 353-366.

Olaru, D., Purchase, S. and Peterson, N. (2008), "From customer value to repurchase intentions and recommendations", Fournal of Business \& Industrial Marketing, Vol. 23 No. 8, pp. 554-565.

Ounnar, F., Pujo, P., Mekaouche, L. and Giambiasi, N. (2007), "Customer-supplier relationship management in an intelligent supply chain network", Production Planning \& Control, Vol. 18 No. 5, pp. 377-387.

Parast, M.M. (2019), “A learning perspective of supply chain quality management: empirical evidence from US supply chains", Supply Chain Management: An International fournal., Vol. 25 No. 1.

Parasuraman, A., Zeithaml, V.A. and Berry, L.L. (1988), "Servqual: a multiple-item scale for measuring consumer perc", fournal of Retailing, Vol. 64 No. 1, p. 12.

Patterson, P.G. and Spreng, R.A. (1997), "Modelling the relationship between perceived value, satisfaction and repurchase intentions in a business-to-business, services context: an empirical examination", International fournal of Service Industry Management, Vol. 8 No. 5, pp. 414-434.

Paulin, M., Ferguson, R.J. and Alvarez Salazar, A.M. (1999), "External effectiveness of service management a study of business-to-business relationships in Mexico, Canada and the USA", International Fournal of Service Industry Management, Vol. 10 No. 5, pp. 409-429.

Provan, K.G. and Milward, H.B. (2001), "Do networks really work? A framework for evaluating public-sector organizational networks", Public Administration Review, Vol. 61 No. 4, pp. 414-423.

Provan, K.G. and Sydow, J. (2008), "Evaluating interorganizational relationships", The Oxford Handbook of InterOrganizational Relations, pp. 691-716.

Ranaweera, C. and Prabhu, J. (2003), "The influence of satisfaction, trust and switching barriers on customer retention in a continuous purchasing setting", International Fournal of Service Industry Management, Vol. 14 No. 4, pp. 374-395.

Rauyruen, P. and Miller, K.E. (2007), "Relationship quality as a predictor of B2B customer loyalty", fournal of Business Research, Vol. 60 No. 1, pp. 21-31.

Reid, D.A. and Plank, R.E. (2000), "Business marketing comes of age: a comprehensive review of the literature", fournal of Business-to-Business Marketing, Vol. 7 Nos 2/3, pp. 9-186.

Ryals, L.J. and Humphries, A.S. (2007), “Managing key business-to-business relationships: what marketing can learn from supply chain management", Fournal of Service Research, Vol. 9 No. 4, pp. 312-326. 
Sánchez-Fernández, R. and Iniesta-Bonillo, M.Á. (2007), "The concept of perceived value: asystematic review of the research", Marketing Theory, Vol. 7 No. 4, pp. 427-451.

Schalk, J., Torenvlied, R. and Allen, J. (2009), "Network embeddedness and public agency performance: the strength of strong ties in Dutch higher education", fournal of Public Administration Research and Theory, Vol. 20 No. 3, pp. 629-653.

Schmid, J.C., Knierim, A. and Knuth, U. (2016), "Policyinduced innovations networks on climate change adaptation-an ex-post analysis of collaboration success and its influencing factors", Environmental Science \& Policy, Vol. 56, pp. 67-79.

Schmitt, B. (1999), "Experiential marketing", Fournal of Marketing Management, Vol. 15 Nos 1/3, pp. 53-67.

Selnes, F. (1998), "Antecedents and consequences of trust and satisfaction in buyer-seller relationships", European fournal of Marketing, Vol. 32 Nos 3/4, pp. 305-322.

Straub, A. (2010), "Competences of maintenance service suppliers servicing end-customers”, Construction Management and Economics, Vol. 28 No. 11, pp. 1187-1195.

$\mathrm{Su}$, J. and Gargeya, V.B. (2016), "Supplier selection in smalland medium-sized firms: the case of the US textile and apparel industry", American foumal of Business, Vol. 31 No. 4, pp. 166-186.

Sutherland, D. (2017), "Observations and lessons learnt from more than a decade of water safety planning in South-East Asia", WHO South-East Asia fournal of Public Health, Vol. 6 No. 2, p. 27.

Tai, D., Dhar, A., Yusuf, A., Marshall, A., O’Beirne, J., Patch, D., ... Thorburn, D. (2018), "The royal free hospital 'huband-spoke network model' delivers effective care and increased access to liver transplantation", Public Health, Vol. 154, pp. 164-171.

Tangpong, C., Michalisin, M.D., Traub, R.D. and Melcher, A.J. (2015), "A review of buyer-supplier relationship typologies: progress, problems, and future directions", Fournal of Business Eீ Industrial Marketing., Vol. 30 No. 2.
Tyler, K., Patton, M., Mongiello, M., Meyer, D., Stan, S., Evans, K.R., ... Stinson, J.L. (2007), "Segment differences in the asymmetric effects of service quality on business customer relationships", fournal of Services Marketing.

Ulaga, W. and Eggert, A. (2006), "Relationship value and relationship quality: broadening the nomological network of business-to-business relationships", European fournal of Marketing, Vol. 40 Nos 3/4, pp. 311-327.

Vargo, S.L. and Lusch, R.F. (2014), "Evolving to a new dominant logic for marketing", In the Service-Dominant Logic of Marketing,Routledge, pp. 21-46.

Vinhas, A.S. and Gibbs, R. (2012), “Competitive channel relationship management: when resellers establish competing manufacturer relationships", Marketing Letters, Vol. 23 No. 3, pp. 645-659.

Vize, R., Coughlan, J., Kennedy, A. and Ellis-Chadwick, F. (2013), "Technology readiness in a B2B online retail context: an examination of antecedents and outcomes", Industrial Marketing Management, Vol. 42 No. 6, pp. 909-918.

Wang, Z. and Horsburgh, S. (2007), "Linking network coherence to service performance: modelling airline strategic alliances", fournal of Marketing Channels, Vol. 14 No. 3, pp. 51-81.

Weiss, E.S., Taber, S.K., Breslau, E.S., Lillie, S.E. and Li, Y. (2010), "The role of leadership and management in six Southern public health partnerships: a study of member involvement and satisfaction", Health Education \& Behavior, Vol. 37 No. 5, pp. 737-752.

Wieland, H., Koskela-Huotari, K. and Vargo, S.L. (2016), "Extending actor participation in value creation: an institutional view", fournal of Strategic Marketing, Vol. 24 Nos 3/4, pp. 210-226.

Zeithaml, V.A. (1988), "Consumer perceptions of price, quality, and value: a means-end model and synthesis of evidence", fournal of Marketing, Vol. 52 No. 3, pp. 2-22.

\section{Corresponding author}

Lucrezia Coletta can be contacted at: lucrezia.coletta@, santannapisa.it 


\section{Appendix}

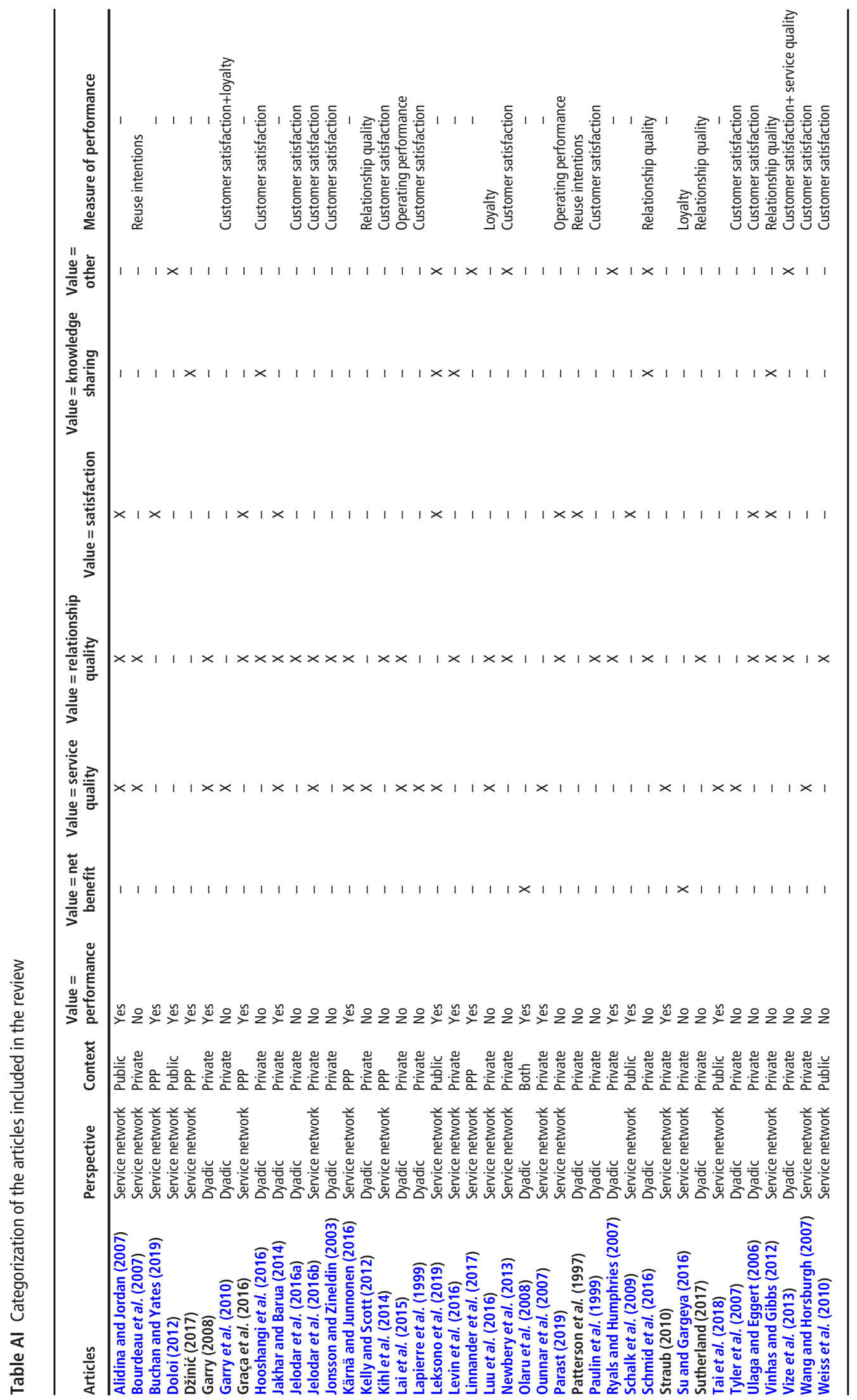

